\title{
Physicochemical Properties of Breadfruit-Bambara Groundnut Flour Blends and Sensory Acceptability of Their Dumpling Dough
}

\author{
Stephen Olanrewaju Arinola* Omolara Adenike Omowaye-Taiwo \\ Department of Food Technology \\ The Federal Polytechnic Ado-Ekiti, P.M.B. 5351 Ado-Ekiti, Ekiti State, Nigeria
}

\begin{abstract}
This study explored the possibility of producing flours from underutilized crops (breadfruit and bambara groundnut) that could replace relatively expensive tuber and cereal flours usually used to prepare dumpling dough, a favourite food item in Sub-sahara Africa. Flours were produced from breadfruit and bambara groundnut, the flours were mixed in the following proportion, $100 \%: 0 \% ; 90 \%: 10 \% ; 80 \%: 20 \% ; 70 \%: 30 \%$ and $60 \%: 40 \%$ respectively to produce five breadfruit-bambara groundnut flour blends. Functional and pasting properties of the flour blends were evaluated using standard methods. Each of the flour blends was made into dumpling dough and the sensory evaluation of the dough was carried out. Commercial whole wheat flour was used as control. The functional properties of the flour blends were: swelling power $5.1-6.2$, water absorption capacity $5.2-6.4 \mathrm{ml} / \mathrm{g}$, oil absorption capacity $1.2-2.6 \mathrm{ml} / \mathrm{g}$, least gelation concentration $10.0-14.0 \%$, dispersibility $57.0-69.0 \%$, wetability $56.0-66.0$ seconds, packed bulk density $0.55-0.66 \mathrm{~g} / \mathrm{ml}$ and loose bulk density $0.32-0.34 \mathrm{~g} / \mathrm{ml}$. Pasting properties of the flour blends were significantly different; peak viscosity, hot paste viscosity, final viscosity and setback viscosity were in the range $468.0-1257.0 \mathrm{cP}, 527.0-1241.0 \mathrm{cP}, 608.0-2317.0 \mathrm{cP}$ and $81.0-1076.0$ $\mathrm{cP}$ respectively. Flour blend produced from $80 \%$ breadfruit flour and $20 \%$ bambara groundnut flour had exceptionally high pasting values. Variation in the functional and pasting properties of the flour blends could enhance their use in different food applications. The result of sensory evaluation of the dumpling dough produced showed that dough produced from $80 \%$ breadfruit flour and $20 \%$ bambara groundnut flour blend was the most preferred and it compared favourably with dumpling dough produced from the control.
\end{abstract}

Keywords: Dumpling dough, functional properties, pasting properties, sensory acceptability

DOI: $10.7176 /$ FSQM/95-05

Publication date:March $31^{\text {st }} 2020$

\subsection{Introduction}

Breadfruit, Artocarpus altilis (Parkinson) Fosberg, is a staple crop in countries of the tropical region of the world. The plant is well adapted to many tropical climates and does well especially in the wet tropics where some other staple crops do not. It is an important energy food crop that contains starch and sugar; it is also rich in fiber and mineral elements (Peters et al. 2016). Additionally, the fruit is known to have a number of secondary metabolites especially flavonoids and flavones which exhibit biological activity and can be of health benefit to the body. Breadfruit has the potential to help alleviate world hunger and increase food security (Liu et. al., 2014), however it is underutilized. Apart from being underutilized, a major limiting factor in the large scale production and utilization of the crop is its short shelf life ( $3-5$ days). Several researchers have reported that effective means to overcome this challenge was to process the fruit into flour which can then be used in various products (Jones et. al., 2011, Peters et. al., 2016, Arinola and Akingbala, 2018). Therefore improved commercial cultivation and utilization of breadfruit will require basic research to evaluate the performance of the crop and its flour in various food products. Breadfruit flour in composite with other flours has been evaluated in bakery products; however the use of breadfruit flour either alone or in composite with bambara groundnut in the production of dumpling dough has not received much research attention.

Bambara groundnut (Voandzeia subterranean L. Verdc) is one of the underutilized legumes in Nigeria. This is partly due to limited information on its nutritional value, potential food uses and hard to cook nature. Its cultivation has several agronomic advantages; it is drought tolerant, it has ability to grow well in poor soil and unfavourable environmental condition (Oyeyinka, 2016). Bambara groundnut contains appreciable quantity of carbohydrate, protein, fat and ash; it is also rich in bioactive compounds that are of tremendous benefit to the body (Nyau et. al., 2017). Bambara groundnut is eaten in several ways and at different level of maturity (Bamshaiye et. al., 2011), it has been used to supplement flours of other crops (Olapade et. al., 2014, Kiin Kabari et. al., 2015). However study on the use of bambara groundnut in combination with breadfruit flour for the production of dumpling dough in Nigeria is scarce. Dumpling dough is essentially a starchy food usually produced from flours of some cereals, roots and tubers, which have low protein content (Jimoh et. al., 2017). Attempt has been made in the past to increase the protein content of this food item in order to enhance its nutritional value especially in developing countries of Sub-sahara Africa where consumption of the food is common and where problem of protein energy malnutrition is endemic. Dumpling dough such as soy amala and soy fufu had been produced from mixture of soy flour with yam flour and fermented cassava flour respectively. As a result of the world food shortage 
caused by several emerging factors it becomes imperative to harness the nutritional and health benefit potentials of hitherto underutilized and neglected crops in the production of foods. The focus of this study is to evaluate the potential of breadfruit-bambara groundnut flour blends, in terms of its functional, pasting and sensory properties, as a replacement to commonly used flours in the production of dumpling dough.

\subsection{Materials and Methods \\ 2.1 Collection of Samples}

The major raw materials used in this study were matured unripe breadfruits obtained from a farm in Ile-Ife, Osun State and bambara groundnut procured from Oja Oba market, Ado-Ekiti, Ekiti State, Nigeria. Commercial whole wheat flour used as control was also obtained from Oja Oba market, Ado-Ekiti, Ekiti State, Nigeria.

\subsection{Production of Breadfruit Flour}

Breadfruit flour was produced by peeling matured unripe breadfruits that has been washed in water. The peeled breadfruits was cored and sliced into tiny pieces to facilitate drying. Breadfruit pieces were dried in hot air oven at $70^{\circ} \mathrm{C}$ for 10 hours. The dried breadfruit pieces were milled into flour using hammer mill, breadfruit flour was thereafter sieved through a fine mesh sieve $(500 \mu \mathrm{m})$ and packaged in moisture-proof polyethylene bag.

\subsection{Production of Bambara groundnut Flour}

Bambara groundnut flour was produced according to the method described by Oyeyinka (2016) with modification. Bambara groundnuts were thoroughly cleaned by picking out all the unwanted materials and sorting out the bad seeds. The cleaned seeds were soaked in water $(1: 4 \mathrm{w} / \mathrm{v})$ for 2 hours, parboiled $\left(100^{\circ} \mathrm{C}\right)$ for 15 minutes and then dehulled manually. The dehulled seeds were dried at $60^{\circ} \mathrm{C}$ for 24 hours in hot air oven, milled into flour, sieved through a fine mesh sieve $(500 \mu \mathrm{m})$ and packaged in moisture-proof polyethylene bag.

\subsection{Formulation of Breadfruit-Bambara Groundnut Flour Blends}

Breadfruit flour and bambara groundnut flour were mixed together in the following proportion, 100\%:0\%; 90\%:10\%; 80\%:20\%; 70\%:30\% and 60\%:40\% respectively. The blends were thoroughly mixed manually, packaged in polyethylene bags and stored at ambient temperature.

\subsection{Functional Properties}

\subsubsection{Swelling}

The swelling power at $60^{\circ} \mathrm{C}$ was determined according to the method described by Kaur et. al. (2011). Briefly $1 \mathrm{~g}$ of flour sample was mixed with $10 \mathrm{ml}$ of distilled water in a previously weighed empty centrifuge tube and heated at $60^{\circ} \mathrm{C}$ for 30 minutes while shaking continuously. The tube was removed from the water bath, wiped dried, cool to ambient temperature and centrifuged at $3200 \mathrm{rpm}$ for 30 minutes. The swollen sample obtained after decanting the supernatant was weighed to determine the swelling power. Swelling power was reported as the ratio of the weight of swollen flour paste to that of dry flour.

2.5.2 Water and oil absorption capacity

Water absorption capacity was determined by using the procedure of Sathe et. al. (1982). $1 \mathrm{~g}$ of flour sample was measured into a centrifuge tube; the sample was mixed thoroughly with $10 \mathrm{ml}$ distilled water for 30 seconds and allowed to stand for 30 minutes at ambient temperature. The sample was then centrifuged at $4000 \mathrm{rpm}$ for 30 minutes after which unabsorbed water was decanted and measured. Water absorption capacity was expressed as volume $(\mathrm{ml})$ of water absorbed per gram of sample. The same procedure was used to determine oil absorption capacity with the replacement of water with vegetable oil.

\subsubsection{Least gelation concentration}

Least gelation concentration was determined according to the method described by Onwuka (2005). $5 \mathrm{ml}$ suspension of each flour sample $(2-20 \% \mathrm{w} / \mathrm{v})$ was prepared in ten test tubes; the test tubes were heated in a boiling water bath $\left(100^{\circ} \mathrm{C}\right)$ for 1 hour, followed by rapid cooling under running water and further cooling at $4^{\circ} \mathrm{C}$ for 2 hours. The concentration (\%) at which the sample did not fall when the tube was inverted was noted to be least gelation concentration.

\subsubsection{Dispersibility}

Dispersibility of the sample was evaluated by weighing $10 \mathrm{~g}$ flour sample into a $100 \mathrm{ml}$ measuring cylinder and adding distilled water to a volume of $100 \mathrm{ml}$. The mixture was stirred vigorously and then allowed to stand for 3 hours. The volume of settled particles was read and subtracted from 100 . The difference between the two values was reported as percentage dispersibility (Adegunwa et. al., 2017).

\subsubsection{Wetability}

For the determination of wetability, $1 \mathrm{~g}$ of flour sample was weighed into $25 \mathrm{ml}$ graduated cylinder, covered with finger and inverted at a height of $10 \mathrm{~cm}$ from $600 \mathrm{ml}$ beaker containing $500 \mathrm{ml}$ distilled water. The finger was removed and the sample was allowed to fall into water. The time required for the sample to be completely wet is 
an index of wetability.

2.5.6 Packed and Loose bulk densities

To determine packed bulk density, $10 \mathrm{ml}$ measuring cylinder was weighed empty and then filled up with the sample. The bottom of the measuring cylinder was tapped on the bench several times until there was no longer reduction in the level of the sample. The measuring cylinder was reweighed and the volume of the sample in the cylinder was also noted. Packed bulk density was expressed as the weight of tapped sample per unit volume. For Loose bulk density, the same procedure was repeated except that the measuring cylinder was not tapped; loose bulk density was expressed as the weight of untapped sample per unit volume.

\subsection{Pasting Properties}

Flour pasting properties were evaluated using Rapid Visco Analyser (RVA 4500; Perten Instruments, Sweden). About $25 \mathrm{ml}$ of water was added to $3 \mathrm{~g}$ sample to produce $12 \%$ flour suspension in the RVA canister; the canister paddle was put in place and its blade was trotted through the suspension for about 8 times to ensure proper mixing of the suspension. The canister, fitted with the paddle, was then placed in the machine as recommended. The 12 minutes profile was used; idle time and temperature were 1 minutes and $50^{\circ} \mathrm{C}$ respectively, sample was heated from $50^{\circ} \mathrm{C}$ to $95^{\circ} \mathrm{C}$ in 3 minutes 45 seconds, held at $95^{\circ} \mathrm{C}$ for 2 minutes 30 seconds and then cooled back to $50^{\circ} \mathrm{C}$ over 3 minutes 45 seconds period, this was followed by 2 minutes period when the temperature was maintained at $50^{\circ} \mathrm{C}$. The following pasting parameters were obtained: peak viscosity, hot paste viscosity, breakdown viscosity, final viscosity, setback viscosity, pasting temperature and peak time.

\subsection{Production and Sensory Evaluation of Dumpling Dough}

The five flour blends were made into dumpling dough by mixing measured quantity of each flour blend with boiling water and continuously stirring the mixture using a wooden paddle. The gelatinized dough was allowed to cook for few minutes with constant stirring until uniform smooth texture dough was obtained. Coded samples of the dumpling dough were served to 20 panelists who are familiar with the sensory attributes of dumpling dough. Taste, aroma, colour, mouthfeel, texture. mouldability and overall acceptability of the samples were evaluated using nine point hedonic scale where 9 represents extremely like and 1 represents dislike extremely. Dough prepared from commercial whole wheat flour was used as control.

\subsection{Statistical Analysis}

The difference in experimental data was tested for statistical significance $p \leq 0.05$ by Statistical Analysis of Variance (ANOVA) using SPSS 21.0 software package (Statistical Package for Social Scientist, Michigan, USA)

\subsection{Results and Discussion \\ 3.1 Functional Properties}

The functional properties of breadfruit-bambara groundnut flour blends are presented in Table 1. There was significant difference in the swelling power of the samples, swelling power of $100 \mathrm{BF}(100 \%$ breadfruit flour) was 6.2; this was reduced progressively, by addition of bambara groundnut flour, to 5.1. This reduction may be due to differences in the starch and protein contents of the two flours, starch and protein are two prominent proximate principles which usually influence water absorption and swelling (Aprianita et. al., 2009). Similar pattern of result was observed for water absorption capacity with $100 \mathrm{BF}$ having the highest and $60 \mathrm{BF} 40 \mathrm{BG}(60 \%$ breadfruit flour $+40 \%$ bambara groundnut flour) having the least. Ability of flour to absorb water and swell is a major attribute of flour intended for production of dumpling dough. The range of swelling power of the samples was comparable with 4.84 - 5.96 reported for breadfruit flour (Arinola and Akingbala, 2018). Water absorption capacity of the flour blends was higher than the range $1.14(114 \%)-1.99(199 \%)$ reported for cassava-bambara groundnut flour blends by Olapade et. al. (2014). Water absorption capacity and swelling power of the flour blends were generally higher than the values ( 3.4 and $1.6 \mathrm{ml} / \mathrm{g}$ respectively) reported for commercial whole wheat flour used as control in this study, this may suggest that dough yield and consistency of breadfruit-bambara groundnut flour blends would be better than that of control (Osundahunsi et. al., 2003). Oil absorption capacity of the samples were low $(1.2-2.6 \mathrm{ml} / \mathrm{g})$, this is acceptable in a sample meant for production of dumpling dough. It appeared that inclusion of bambara groundnut increased the capacity of the flour blends to absorb oil even though this was not the case at higher level of bambara groundnut inclusion. Least gelation concentration of sample $100 \mathrm{BF}$ was $10.0 \%$, this increased to $14.0 \%$ in the flour blends that contained $30 \%$ and $40 \%$ bambara groundnut flour. Increased in addition of bambara groundnut flour, which has higher protein content than breadfruit flour, may have increased protein content of the flour blends; such increase may have contributed to high least gelation concentration due to reduced thermodynamic affinity of protein for aqueous solution. Similar increase in least gelation concentration of cassava flour supplemented with bambara groundnut was reported by Olapade et. al.(2014). The least gelation concentration is a measure of gelation and it indicates the minimum flour concentration at which a stable gel is formed. Moderate gelation concentration as reported for breadfruit-bambara groundnut flour blends in this study 
is preferable in food products such as dumpling dough.

There was significant difference in the dispersibility of the flour blends, which ranged from 57.0 to $69.0 \%$. It was observed that the values reduced as the level of bambara groundnut in the flour blends increased. Bambara groundnut, being a leguminous crop, contains higher fat content than breadfruit flour; its inclusion in the flour blends might have increased the hydrophobic constituents with consequent reduction in the dispersibility ability of the sample. Dispersibility is the degree of ease of reconstituting flour in water and it reflects how the components of the flour are able to disperse and homogenize within the aqueous medium. High dispersibility indicates low tendency of the flour to form clumps during mixing, resulting in smooth dough or pastes, which is ideal for various food products (Adegunwa et. al., 2017). The control however had higher dispersibility value than the flour blends produced in this study. There was fluctuation in the wetability values of breadfruit-bambara groundnut flour blends, which were significantly higher than that of the control. The packed bulk density of the flour blends ranged from 0.55 to $0.66 \mathrm{~g} / \mathrm{ml}$ with $100 \mathrm{BF}$ having the highest while 60BF40BG had the lowest. However the result of loose bulk density did not follow any particular pattern. Generally bulk density is a measure of how compacted the flour is and it has implication on packaging and transportation of food materials. The relatively lower packed and loose bulk densities of the flour blends when compared with that of control indicates that lower quantity (gram) of the sample would occupy more space resulting in bigger packaging materials per unit quantity (gram). This would ultimately affect packaging and transportation cost.

Table 1: Functional Properties of Breadfruit-Bambara Groundnut Flour Blends

\begin{tabular}{lcccccccc}
\hline Sample & $\begin{array}{c}\text { Swelling } \\
\text { Power } \\
@\end{array}$ & $\begin{array}{c}\text { WAC } \\
(\mathrm{ml} / \mathrm{g})\end{array}$ & $\begin{array}{c}\text { OAC } \\
(\mathrm{ml} / \mathrm{g})\end{array}$ & $\begin{array}{c}\text { LGC }(\%) \\
\text { (a) }\end{array}$ & $\begin{array}{c}\text { Dispersibility } \\
(\%)\end{array}$ & $\begin{array}{c}\text { Wetability } \\
(\mathrm{seconds})\end{array}$ & $\begin{array}{c}\text { PBD } \\
(\mathrm{g} / \mathrm{ml})\end{array}$ & $\begin{array}{c}\text { LBD } \\
(\mathrm{g} / \mathrm{ml})\end{array}$ \\
\hline 100BF & $6.2 \pm 0.2^{\mathrm{a}}$ & $6.4 \pm 0.1^{\mathrm{a}}$ & $2.2 \pm 0.0^{\mathrm{b}}$ & $10.0 \pm 0.0^{\mathrm{b}}$ & $69 \pm 2.0^{\mathrm{b}}$ & $64 \pm 1.0^{\mathrm{a}}$ & $0.66 \pm 0.02^{\mathrm{b}}$ & $0.32 \pm 0.01^{\mathrm{b}}$ \\
90BF10BG & $5.8 \pm 0.1^{\mathrm{b}}$ & $5.6 \pm 0.2^{\mathrm{bc}}$ & $2.6 \pm 0.1^{\mathrm{a}}$ & $10.0 \pm 0.0^{\mathrm{b}}$ & $63 \pm 1.0^{\mathrm{c}}$ & $65 \pm 1.0^{\mathrm{a}}$ & $0.57 \pm 0.03^{\mathrm{c}}$ & $0.34 \pm 0.01^{\mathrm{b}}$ \\
80BF20BG & $6.0 \pm 0.1^{\mathrm{ab}}$ & $5.8 \pm 0.2^{\mathrm{b}}$ & $2.6 \pm 0.1^{\mathrm{a}}$ & $10.0 \pm 0.0^{\mathrm{b}}$ & $64 \pm 1.0^{\mathrm{c}}$ & $64 \pm 3.0^{\mathrm{a}}$ & $0.57 \pm 0.02^{\mathrm{c}}$ & $0.34 \pm 0.02^{\mathrm{b}}$ \\
$70 \mathrm{BF} 30 \mathrm{BG}$ & $5.4 \pm 0.1^{\mathrm{c}}$ & $5.4 \pm 0.2^{\mathrm{cd}}$ & $2.0 \pm 0.0^{\mathrm{c}}$ & $14.0 \pm 0.0^{\mathrm{a}}$ & $63 \pm 2.0^{\mathrm{c}}$ & $66 \pm 2.0^{\mathrm{a}}$ & $0.55 \pm 0.02^{\mathrm{c}}$ & $0.33 \pm 0.01^{\mathrm{b}}$ \\
60BF40BG & $5.1 \pm 0.2^{\mathrm{d}}$ & $5.2 \pm 0.2^{\mathrm{d}}$ & $1.2 \pm 0.2^{\mathrm{d}}$ & $14.0 \pm 0.0^{\mathrm{a}}$ & $57 \pm 1.0^{\mathrm{d}}$ & $56 \pm 2.0^{\mathrm{b}}$ & $0.55 \pm 0.02^{\mathrm{c}}$ & $0.32 \pm 0.02^{\mathrm{b}}$ \\
Control & $3.4 \pm 0.2^{\mathrm{e}}$ & $1.6 \pm 0.2^{\mathrm{e}}$ & $2.0 \pm 0.1^{\mathrm{c}}$ & $10.0 \pm 0.0^{\mathrm{b}}$ & $74 \pm 0.2^{\mathrm{a}}$ & $52 \pm 0.0^{\mathrm{c}}$ & $0.78 \pm 0.01^{\mathrm{a}}$ & $0.48 \pm 0.01^{\mathrm{a}}$ \\
\hline
\end{tabular}

Values in the same column with different superscript are significantly different $(\mathrm{p} \leq 0.05)$

$100 \mathrm{BF}=100 \%$ Breadfruit flour

$90 \mathrm{BF} 10 \mathrm{BG}=90 \%$ Breadfruit flour $+10 \%$ Bambara groundnut flour

$80 \mathrm{BF} 20 \mathrm{BG}=80 \%$ Breadfruit flour $+20 \%$ Bambara groundnut flour

70BF30BG $=70 \%$ Breadfruit flour $+30 \%$ Bambara groundnut flour

$60 \mathrm{BF} 40 \mathrm{BG}=60 \%$ Breadfruit flour $+40 \%$ Bambara groundnut flour

$\mathrm{WAC}=$ Water Absorption Capacity; OAC $=$ Oil Absorption Capacity; LGC $=$ Least Gelation Concentration

PBD = Packed Bulk Density; LBD = Loose Bulk Density

\subsection{Pasting Properties}

Table 2 shows the pasting properties of breadfruit-bambara groundnut flour blends. The peak viscosity of the flour blends ranged from 468.0 to $1257.0 \mathrm{cP}$. Inclusion of bambara groundnut flour in the blend reduced the peak viscosity of the blends, this may be due to dilution effect of protein and fat in bambara groundnut and pregelatinization of available starch in bambara groundnut during production of bambara groundnut flour. However sample $80 \mathrm{BF} 20 \mathrm{BG}$ ( $80 \%$ breadfruit flour $+20 \%$ bambara groundnut flour $)$ had an unexpected high peak viscosity, this may be due to optimum interaction of both starchy and non starchy components of the two flours in the blends. High water absorption capacity and swelling power of sample 80BF20BG may also have contributed to this observation. High water absorption and swelling has been reported to be indicative of higher peak viscosity (Shittu et. al., 2001). Peak viscosity, which is the maximum viscosity achieved during heating, is often correlated with final product quality. The relatively high peak viscosity of samples 100BF and 80BF20BG indicate their ability to form sticky dough which is preferable by consumers.

During the hold stage of the pasting test, when sample is held at high temperature $\left(95^{\circ} \mathrm{C}\right)$ with constant and continuous mixing, there is usually reduction in viscosity due to rupturing and fragmentation of starch granules (Damodaran et. al., 2008; Sandhu and Singh, 2007). The minimum viscosity during this isothermal stage is termed hot paste viscosity. The hot paste viscosity of the breadfruit-bambara groundnut flour blends ranged from 527.0 to $1241.0 \mathrm{cP}$ for samples 70BF30BG $(70 \%$ breadfruit flour $+30 \%$ bambara groundnut flour) and $80 \mathrm{BF} 20 \mathrm{BG}$ respectively. It was observed in this study that with the exception of sample 80BF20BG, other sample did not show any reduction in viscosity during isothermal stage rather the viscosity increased, this indicate that there was no breakdown and the samples were able to withstand heating and shear stress. This observation may be due to the integrity of breadfruit starch granules which do not readily disintegrate. On the contrary, the control sample showed huge reduction during isothermal stage from 1668.0 to $1121.0 \mathrm{cP}$ with a relatively higher breakdown value of $547.0 \mathrm{cP}$. This may have contributed to the high sensory score given to the control sample especially in terms 
of texture during sensory evaluation (Table 3). Breakdown viscosity, which is the difference between peak viscosity and hot paste viscosity, was negative for all the breadfruit-bambara groundnut flour samples except for sample 80BF20BG whose value was $16.0 \mathrm{cP}$. Breakdown viscosity has positive correlation with degree of starch granules disintegration and formation of starch gel, which are essential for smooth, elastic and less hard dough preferable by most consumers. This result suggest that amidst the breadfruit-bambara groundnut flour blends 80BF20BG flour blend would produced dumpling dough that would be better in terms of texture, this observation was reflected in the sensory evaluation of dumpling dough (Table 3).

The pattern of final viscosity of the flour blends was similar to that of peak viscosity. Sample 80BF20BG had the highest value, its value was the closest to $2727.0 \mathrm{cP}$ obtained for commercial whole wheat flour used as control, indicating its superiority among the flour blends to form a good textural quality dumpling dough after cooking and cooling. Setback viscosity of the flour blends ranged from 81.0 to $1076.0 \mathrm{cP}$, the setback values of the blends were lower than that of control. Setback viscosity, which is the extent of increase in viscosity on cooling to $50^{\circ} \mathrm{C}$, reflects the tendency of sample to undergo retrogradation, lower setback during the cooling of the paste indicates greater resistance to retrogradation (Sandhu et al., 2007). Retrogradation makes dough to become stiffer, firmer and increasingly resistant to enzyme hydrolysis. The result thus suggests that dough produced from the flour blends with lower setback values would be less susceptible to retrogradation when compared to dough produced from commercial whole wheat flour. This is of nutritional advantage because such dough will be less resistant to enzyme hydrolysis and have improved digestibility when consumed. There was no significant difference in the peak time of all the flour blends except sample 80BF20BG. Sample 80BF20BG and the control had significantly lowest peak time of 5.73minutes. Peak time connotes ease of cooking. Peak time of breadfruit flour (100BF) was higher than 6.07 minutes reported for plantain flour (Arinola et. al., 2016). There were significant differences in the pasting temperatures of the samples, pasting temperature of all the flour blends were significantly lower than that of control. High pasting temperature has been reported to be an indication of high restriction to swelling (Kaur and Singh, 2005). The flour blends are therefore expected to exhibit less restriction to swelling, this is reflected in the high swelling power of the flour samples when compared with control. The range of pasting temperature of the breadfruit-bambara groundnut flour blends reported in this study is comparable with $75.87-77.45^{\circ} \mathrm{C}$ reported for cassava-bambara groundnut flour blends (Olapade et. al., 2014). Pasting temperature, which is the temperature at the onset of rise in viscosity, gives a measure of minimum temperature required to cook a given food sample. The combination of pasting temperature and peak time has implication on the energy cost of preparing a food sample.

Table 2: Pasting Properties of Breadfruit-Bambara Groundnut Flour Blends

\begin{tabular}{lccccccc}
\hline & $\begin{array}{c}\text { Peak } \\
\text { Viscosi } \\
\text { ty (cP) }\end{array}$ & $\begin{array}{c}\text { Hot Paste } \\
\text { Viscosity } \\
(\mathrm{cP})\end{array}$ & $\begin{array}{c}\text { Breakdown } \\
\text { Viscosity }(\mathrm{cP})\end{array}$ & $\begin{array}{c}\text { Final } \\
\text { Viscosity } \\
(\mathrm{cP})\end{array}$ & $\begin{array}{c}\text { Setback } \\
\text { Viscosity } \\
(\mathrm{cP})\end{array}$ & $\begin{array}{c}\text { Peak } \\
\text { Time } \\
(\text { Mins })\end{array}$ & $\begin{array}{c}\text { Pasting } \\
\text { Temp. } \\
\left({ }^{\circ} \mathrm{C}\right)\end{array}$ \\
\hline $\begin{array}{l}\text { 100BF } \\
\text { 90BF10 }\end{array}$ & $1058.0^{\mathrm{c}}$ & $1122.0^{\mathrm{b}}$ & $-64.0^{\mathrm{c}}$ & $1892.0^{\mathrm{c}}$ & $770.0^{\mathrm{c}}$ & $7.00^{\mathrm{a}}$ & $78.20^{\mathrm{c}}$ \\
BG & $862.0^{\mathrm{d}}$ & $924.0^{\mathrm{c}}$ & $-62.0^{\mathrm{c}}$ & $1585.0^{\mathrm{d}}$ & $661.0^{\mathrm{d}}$ & $6.93^{\mathrm{a}}$ & $79.10^{\mathrm{bc}}$ \\
$\begin{array}{l}80 \mathrm{BF} 20 \\
\text { BG }\end{array}$ & $1257.0^{\mathrm{b}}$ & $1241.0^{\mathrm{a}}$ & $16.0^{\mathrm{b}}$ & $2317.0^{\mathrm{b}}$ & $1076.0^{\mathrm{b}}$ & $5.73^{\mathrm{b}}$ & $78.25^{\mathrm{c}}$ \\
$70 \mathrm{BF} 30$ & & & & & & & \\
BG & $468.0^{\mathrm{f}}$ & $527.0 \mathrm{e}$ & $-59.0^{\mathrm{c}}$ & $608.0^{\mathrm{f}}$ & $81.0^{\mathrm{f}}$ & $7.00^{\mathrm{a}}$ & $67.70^{\mathrm{d}}$ \\
$\begin{array}{l}\text { 60BF40 } \\
\text { BG }\end{array}$ & $512.0^{\mathrm{e}}$ & $570.0^{\mathrm{d}}$ & $-58.0^{\mathrm{c}}$ & $1014.0^{\mathrm{e}}$ & $444.0^{\mathrm{e}}$ & $7.00^{\mathrm{a}}$ & $79.95^{\mathrm{b}}$ \\
Control & $1668.0^{\mathrm{a}}$ & $1121.0^{\mathrm{b}}$ & $547.0^{\mathrm{a}}$ & $2727.0^{\mathrm{a}}$ & $1606.0^{\mathrm{a}}$ & $5.73^{\mathrm{b}}$ & $87.15^{\mathrm{a}}$ \\
\hline
\end{tabular}

Values in the same column with different superscript are significantly different $(\mathrm{p} \leq 0.05)$

$100 \mathrm{BF}=100 \%$ Breadfruit flour

90BF $10 \mathrm{BG}=90 \%$ Breadfruit flour $+10 \%$ Bambara groundnut flour

$80 \mathrm{BF} 20 \mathrm{BG}=80 \%$ Breadfruit flour $+20 \%$ Bambara groundnut flour

$70 \mathrm{BF} 30 \mathrm{BG}=70 \%$ Breadfruit flour $+30 \%$ Bambara groundnut flour

$60 \mathrm{BF} 40 \mathrm{BG}=60 \%$ Breadfruit flour $+40 \%$ Bambara groundnut flour

\subsection{Sensory Acceptability}

A cursory look at the result of sensory evaluation as presented in Table 3 shows that dumpling dough produced from 80BF20BG was the most preferred among the breadfruit-bambara groundnut flour blends in all the attributes evaluated in this study. The level of inclusion of bambara groundnut flour in the flour blends affected the taste perception of dumpling dough samples, sample produced from 80BF20BG was the most preferred among the dough produced from the flour blends with a mean sensory score of 6.77 followed closely by sample 70BF30BG with a score of 6.46. There was no significant difference in the taste score of these two samples and that of control sample. This suggests that in terms of taste dumpling dough produced from these two flour blends compared 
favourably with dumpling dough produced from commercial whole wheat flour which was used as control. The least score for aroma was given to sample 60BF40BG, this may be attributed to the characteristic aroma of high proportion of bambara groundnut in the flour blend.

In terms of colour there was no significant difference in the values reported for all the dumpling dough produced from the flour blends and the control with the exception of sample 60BF40BG which had the lowest score (6.00). This observation may be due to high level of bambara groundnut flour in the sample which might have resulted into browning as a result of carbonyl amine reaction between sugar in breadfruit flour and protein in bambara groundnut flour. Though varied in score, there was no significant difference in the mouthfeel scores of dumpling dough samples produced from 100BF, 90BF10BG $(90 \%$ breadfruit flour $+10 \%$ bambara groundnut flour), 80BF20BG and the control. However samples 70BF30BG and 60BF40BG were the least preferred, this may be due to high level of bambara groundnut in the sample. In terms of texture, most panelists gave the highest score (7.05) to dumpling dough sample produced from 80BF20BG amidst dough samples produced from the breadfruit-bambara groundnut flour blends, with others following 90BF10BG, 70BF30BG, 100Bf and 60BF40BG in that order. However, the texture score of dumpling dough produced from the flour blends were significantly lower than that of the control. The mouldability sensory scores $(6.31-7.23)$ of dumpling dough produced from the flour blends were higher than that (4.23) of the control. Sample 80BF20BG was perceived as the best in terms of mouldability. Overall acceptability assessment showed that dumpling dough produced from 80BF20BG was most preferred with a sensory score of 7.31 which compared favourably with that (7.77) of the control sample.

Table 3: Mean Sensory Scores of Dumpling Dough Produced From BreadfruitBambara Groundnut Flour Blends

\begin{tabular}{llllcccc}
\hline & & & & & & & Overall \\
Samples & Taste & Aroma & Colour & Mouthfeel & Texture & Moudability & Acceptability \\
\hline 100BF & $5.31^{\mathrm{c}}$ & $5.50^{\mathrm{b}}$ & $6.77^{\mathrm{ab}}$ & $7.39^{\mathrm{a}}$ & $5.75^{\mathrm{c}}$ & $6.77^{\mathrm{a}}$ & $5.54^{\mathrm{d}}$ \\
90BF10BG & $5.46^{\mathrm{bc}}$ & $5.46^{\mathrm{b}}$ & $6.86^{\mathrm{ab}}$ & $7.31^{\mathrm{a}}$ & $6.00^{\mathrm{c}}$ & $6.62^{\mathrm{a}}$ & $6.23^{\mathrm{cd}}$ \\
80BF20BG & $6.77^{\mathrm{a}}$ & $6.97^{\mathrm{a}}$ & $7.08^{\mathrm{ab}}$ & $7.25^{\mathrm{a}}$ & $7.05^{\mathrm{b}}$ & $7.23^{\mathrm{a}}$ & $7.31^{\mathrm{ab}}$ \\
70BF30BG & $6.46^{\mathrm{ab}}$ & $6.90^{\mathrm{a}}$ & $6.69^{\mathrm{ab}}$ & $6.75^{\mathrm{b}}$ & $5.90^{\mathrm{c}}$ & $6.92^{\mathrm{a}}$ & $6.69^{\mathrm{bc}}$ \\
60BF40BG & $5.46^{\mathrm{bc}}$ & $5.23^{\mathrm{b}}$ & $6.00^{\mathrm{b}}$ & $6.65^{\mathrm{b}}$ & $5.55^{\mathrm{c}}$ & $6.31^{\mathrm{a}}$ & $5.92^{\mathrm{cd}}$ \\
Control & $7.54^{\mathrm{a}}$ & $7.69^{\mathrm{a}}$ & $7.54^{\mathrm{a}}$ & $7.46^{\mathrm{a}}$ & $8.00^{\mathrm{a}}$ & $4.23^{\mathrm{b}}$ & $7.77^{\mathrm{a}}$ \\
\hline
\end{tabular}

Values in the same column with different superscript are significantly different $(\mathrm{p} \leq 0.05)$

$100 \mathrm{BF}=100 \%$ Breadfruit flour

90BF10BG $=90 \%$ Breadfruit flour $+10 \%$ Bambara groundnut flour

$80 \mathrm{BF} 20 \mathrm{BG}=80 \%$ Breadfruit flour $+20 \%$ Bambara groundnut flour

$70 \mathrm{BF} 30 \mathrm{BG}=70 \%$ Breadfruit flour $+30 \%$ Bambara groundnut flour

$60 \mathrm{BF} 40 \mathrm{BG}=60 \%$ Breadfruit flour $+40 \%$ Bambara groundnut flour

\subsection{Conclusion}

Flour blends were produced from breadfruit and bambara groundnut, two underutilized crops. The flour blends showed variant functional and pasting properties and could be adopted to replace relatively expensive flours such as whole wheat flour, yam flour commonly used to produce dumpling dough. This study has also shown that it is possible to produce acceptable dumpling dough from flour blend of $80 \%$ breadfruit flour and $20 \%$ bambara groundnut flour. More research could be done on the application of the flour blends in other food products.

\section{References}

Adegunwa, M. O., Sanni, L. O. and Adegoke, G. O. (2017). Physicochemical, functional and sensory properties of bread from cassava and sweet potato starches. Cameroon Journal of Agricultural Science 3 (2): 29 - 36.

Aprianita, A., Purwandari, U., Watson, B. and Vasiljevic, T. (2009). Functional and Pasting properties of flours from selected commercial tubers available in Australia. International Food Research Journal 16: 507 - 520.

Arinola, S. O. and Akingbala, J. O. (2018): Effect of pretreatment on the chemical, functional and storage properties of breadfruit (Artocarpus altilis) flour. International Food Research Journal 25 (1): 109 - 118.

Arinola, S. O., Ogunbusola, E. M. and Adebayo, S. F. (2016). Effect of Drying Methods on the Chemical, Pasting and Functional Properties of Unripe Plantain (Musa paradisiaca) Flour. British Journal of Applied Science \& Technology 14(3): 1-7, 2016.

Bamshaiye, O., Adegbola, J. and Bamshaiye, E. (2011). Bambara groundnut: An under-utilized nut in Africa Advances in Agricultural Biotechnology 1: 60-72.

Damodaran, S., Parkin, K. L. and Fennema, O. R. (2008). Fennema's Food Chemistry $4^{\text {th }}$ edition CRC Press Taylor and Francis Group. 66 -67, 370, 389.

Jimoh, K.O., Babalola, J.O. and Adedokun, S.O. (2017). Evaluation of cocoyam cormels and their sections' flours for a traditional stiff porridge amala. Food Science and Quality Management 60: 87 - 94

Jones, A. M. P, Ragone, D., Tavana, N. G., Bernotas, D. W. and Murch, S. J. (2011). Beyond the bounty:Breadfruit 
(Artocarpus altilis) for food security and noverl foods in the $21^{\text {st }}$ century. Ethnobotany Research \& Applications 9: 129-149.

Kaur, M., Oberoi, D. P. S., Sogi, D. S. and Gill, B. S. (2011). Physicochemical, morphological and pasting properties of acid treated starches from different botanical sources. Food Science and Technology 48(4): 460465.

Kaur, M. and Singh, N. (2005). Studies on functional, thermal and pasting properties of flours from different chickpea (Cicer arietinum L.) cultivars. Food Chemistry. 91: $403-411$.

Kiin-Kabari, D. B., Eke-Ejiofor, J. and Giami, S. Y. (2015). Functional and pasting properties of wheat/plantain

flours enriched with bambara groundnut protein concentrate. International Journal of Food Science and Nutrition Engineering 2015, 5(2): 75-81 doi:10.5923/j.food.20150502.01

Liu, Y., Jones, M. P., Murch, S. J. and Ragone, D. (2014). Crop productivity, yield and seasonality of breadfruit (Artocarpus spp., Moraceae). Fruits 69: 345 - 361. DOI: 10.1051/fruits/2014023

Nyau, V., Prakash, S., Rodrigues, J. and Farrant, J. (2017). Profiling of Phenolic Compounds in Sprouted Common Beans and Bambara Groundnuts. Journal of Food Research 6 (6): $74-82$

Olapade, A. A., Babalola, Y. O. and Aworh, O. C. (2014). Quality attributed of fufu (fermented cassava) flour supplemented with bambara flour. International Food Research Journal 21 (5): 2025 - 2032.

Onwuka, G. I. (2005): Food Analysis and Instrumentation; Theory \& Practice. Lagos, Nigeria: Naphthali Prints, Chapter 10, 133.

Osundahunsi, O. F., Fagbemi, T. N., Kesselman, E, Shimoni, E. (2003). Comparison of the physiochemical properties and pasting characteristics of flour and starch from red and white sweet potato cultivars. Journal of Agriculture and Food Chemistry 51: 2232 - 2236.

Oyeyinka, A. T. (2017). Nutritional, sensory and functional properties of a bambara groundnut complementary food.

Ph.D. Thesis, Department of Dietetics and Human Nutrition, University of KwaZulu-Natal , Pietermaritzburg South Africa.

Peters, H., Mgbang, J. E., Essien, N. A. and Ikpeme, C. E. (2016). Nutritional Evaluation of Breadfruit and Beniseed Composite Flours. American Journal of Food Science and Technology, 4 (6): 182-187. doi: 10.12691/ajfst-4-6-5.

Sandhu, K. S., Singh, N. and Malhi, N. S. (2007). Some properties of corn grains and their flours I: Physicochemical, functional and chapati-making properties of flours. Food Chemistry 101: 938-946.

Sandhu, K. S. and Singh, N. (2007). Some properties of corn starches II: Physicochemical, gelatinization, retrogradation, pasting and gel textural properties. Food Chemistry 101(2007): 1499-1507.

Sathe, . K., Desphande, U. and Salunkhe, K. (1982). Functional properties of Lupinus mutabilis proteins. Journal of Food Science 47:491-497.

Shittu, T. A., Lasekan, O. O., Sanni L. O. and Oladosu, M . O. (2001). The effect of drying methods on the functional and sensory characteristics of pupuru - a fermented cassava product. ASSET - An International Journal 1 (2): 9 - 16. 